\title{
МІКРО- I МАКРОЕЛЕМЕНТНИЙ ОБМІН У ХВОРИХ НА НЕАЛКОГОЛЬНУ ЖИРОВУ ХВОРОБУ ПЕЧІНКИ I ПРИ IIÏ ПОЄДНАННІ З ЦУКРОВИМ ДІАБЕТОМ 2 ТИПУ*
}

\author{
Журавльова Л. В., Лахно О. В., Цівенко О. І., Кривоносова О. М. \\ Харківський національний медичний університет, м. Харків, Украӥна \\ dr.lakhnoolga@gmail.com
}

У наш час спостерігається епідемічне зростання захворюваності на цукровий діабет (ЦД) 2 типу. 3 усієї кількості осіб з ЦД приблизно 90\% складають паціенти з ЦД 2 типу [1], що обумовлено зниженням фізичної активності, нераціональним харчуванням, ожирінням і генетичними факторами [2]. Неалкогольна жирова хвороба печінки (НАЖХП) є частою причиною хронічних захворювань печінки в багатьох розвинених країнах. Дані епідеміологічних досліджень [3] підтверджують тенденцію до збільшення захворюваності НАЖХП у паціентів з резистентністю до інсуліну, що виникае на тлі ожиріння, ЦД 2 типу та наявності метаболічного синдрому. Перераховані вище захворювання мають спільні патогенетичні фактори, які е причиною їх розвитку і прогресування, тобто можуть поєднуватися і підсилювати розвиток один одного [4].

Вміст мікро- і макроелементів (ME) у здоровому організмі, його органах і тка- нинах підтримуеться в певних рамках. Баланс ME обумовлений іх важливою роллю в процесах життедіяльності. Вони беруть участь в множинних процесах комплексоутворення з природними лігандами, такими як нуклеїнові кислоти, пептиди, вуглеводи, білки, гормони, вітаміни та забезпечують їх біологічні функції [5].

Печінка відіграе важливу роль в метаболізмі МЕ в тому числі бере участь в транспортуванні і зберіганні багатьох МЕ. Крім того, печінка виробляе зв'язувальні, транспортні та регуляторні білки, які потрібні для підтримання гомеостазу МЕ. Наприклад, цинк та інші МЕ пов'язані з альбуміном. Таким чином, дефіцит цинку безпосередньо пов'язаний з гіпоальбуминеміею, яка виникае в результаті печінкової синтетичної дисфункції. Крім того, білок металотіонеїнів частково синтезуеться в печінці i функціонуе як хелатор металу і транспортний білок. Печінка також синтезуе жовч

* Роботу виконано в межах планової наукової тематики Харківського національного медичного університету «Оптимізація діагностики та лікування кардіоваскулярних порушень у хворих на цукровий діабет 2 типу в умовах поєднаної патології» (державний реєстраційний № 0118 U 000950).

Установою, що фінансуе дослідження, е МОЗ України.

Автори гарантують повну відповідальність за все, що опубліковано в статті.

Автори гарантують відсутність конфлікту інтересів і власної фінансової зацікавленості при виконанні роботи та написанні статті.

Рукопис надійшов до редакції 28.12.2020. 
(процес, регульований частково за допомогою фрарнезоідного Х-рецептора жовчної кислоти). Жовч необхідна для емульгування жирів і поглинання жиророзчинних вітамінів, і, в свою чергу, жиророзчинні вітаміни регулюють їх власне поглинання шляхом регулювання синтезу жовчних кислот в печінці. Знаущість МЕ в патогенезі ЦД та його ускладнень обумовлена антиоксидантними властивостями, які ME виявляють у зв'язаному з ферментами системи антиоксидантного захисту вигляді. Крім того, участь МЕ в метаболічних процесах залежить також від виконуючих транспортну функцію плазмових білків, обмін яких в більшості залежить від стану печінки. Концентрація деяких МЕ дозволяе судити про активність і ступінь вираженості патологічного процесу в печінці. Такий взаємозв'язок антиоксидантного та біоелементного статусів важливий для розуміння ролі МЕ в патогенезі різних захворювань, оскільки за сучасними уявленнями саме окислювальний стрес відіграє ключову роль у розвитку патологічних процесів в організмі $[6,10]$.

Вивчення стану біоелементного обміну є ще однією сходинкою до вдосконалення методів діагностики і лікування хворих на НАЖХП в поєднанні з ЦД 2-го типу в залежності від індексу маси тіла (IMT), i сприятиме запобіганню подальшого розвитку захворювання.

Мета роботи - вивчити зміни концентрації цинку, магнію, заліза, кальцію, калію, натрію, міді, а також з'ясувати зв'язок між концентраціями біоелементів 3 показниками функціонального стану печінки у хворих на НАЖХП і при її поєднанні з ЦД 2 типу в залежності від (IMT).

\section{МАТЕРІАЛИ ТА МЕТОДИ}

Протокол дослідження був затверджений Комітетом з біоетики Харківського національного медичного університету (реестраційний номер 0118U000950). Учасники, які відповідали критеріям, були проінформовані про методологію дослідження, його цілі, завдання, показання й можливі ускладнення до реестрації.

Обстежено 75 паціентів, що знаходились на лікуванні в гастроентерологічному та ендокринологічному відділеннях КНП ХОР «ОКЛ» м. Харкова, з них 36 чоловіків і 39 жінок, тривалістю захворювання від 3 до 15 років. Середній вік пацієнтів складав 53,8 роки. Було обстежено 3 групи хворих: $1-20$ хворих з ізольованою НАЖХП з нормальною масою тіла, 2 - 20 пацієнтів з НАЖХП в поєднанні з ЦД 2 типу і нормальною масою тіла і 3 -я -35 хворих НАЖХП з ЦД 2 типу та ожирінням. Контрольну групу складали 20 здорових волонтерів репрезентативних за віком та статтю.

Критеріями включення пацієнтів у дослідження були: жінки і чоловіки у віці від 20 до 75 років; встановлений підтверджений діагноз НАЖХП та ЦД 2 типу. Критеріями виключення 3 дослідження були: ЦД 1 типу, ЦД 2 типу в стадії деком- пенсації, патологічне та вторинне ожиріння, тяжкі соматичні та психічні розлади, вірусний гепатит, зловживання алкоголем, використання гепатотоксичних препаратів, хронічні захворювання шлунково-кишкового тракту.

Діагноз ЦД 2 типу встановлювали відповідно до класифікації порушень глікемії (ВОО3, 1999 р.), а також згідно з уніфікованим клінічним протоколом первинної, вторинної (спеціалізованої) та третинної (високоспеціалізованої) медичної допомоги: цукровий діабет 2 типу (наказ МОЗ України № 1118 від 21.12.2012 р.). Для верифікації діагнозу ЦД 2 типу і визначення стану вуглеводного обміну проводилося дослідження рівня глюкози в сироватці крові натще, визначення глікозильованого гемоглобіну (HbA1c), інсуліну та індексу HOMA-IR.

Наявність та ступінь ожиріння встановлювали на підставі розрахунку IMT відповідно до критеріїв ВООЗ (1997). Показник, що стандартизуе масу тіла відповідно до зросту - індекс Кетле, або IMT. Значення IMT розраховували за формулою:

$$
\operatorname{IMT}\left(\kappa \Gamma / M^{2}\right)=\frac{\text { масса тела }(\kappa г)}{\text { зріст }\left(\mathrm{M}^{2}\right)}
$$


Згідно 3 індексом Кетле, нормальна маса тіла була констатована при IMT

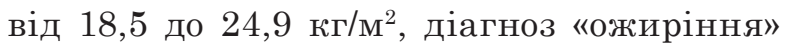

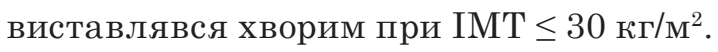

Програма дослідження включала верифікацію клінічного діагнозу, визначення дисбалансу метаболізму біоелементів (цинку, магнію, заліза, кальцію, калію, натрію, міді), оцінку структурно-фрункціонального стану печінки, вуглеводного та білкового обмінів. Печінкові проби (аспартатамінотрансфераза (АСТ), аланінамінотрансфераза (АЛТ), гаммаглутамінтрансфераза (ГГТ), загальний білірубін, лужна фросфратаза (ЛФ) проводились кінетичними та фрерментативно-колориметричними методами із використанням аналізаторів і тест-систем Cobas 6000, Roche Diagnostics (Швейцарія). Глікований гемоглобін визначався імунотурбидиметричним методом аналізатором і тест-системою Cobas 6000, Roche Diagnostics (Швейцарія). Індекс інсулінорезистентності НОМА розраховували за формулою: HOMA = (глюкоза натще, ммоль/л) $\times($ інсулін натще, мкОд/мл)/22,5. Для визначення мікро- і макроелементного складу сироватки крові був обраний метод полум'яної фротометрії з використанням приладу ПАЖ-І (полум'яний аналізатор рідини і атомноадсорбційний спектрофотометр) 3 використанням приладу «Сатурн».

Діагноз НАЖХП встановлювали відповідно до уніфікованого клінічного протоколу «Неалкогольний стеатогепатит» (2014) та адаптованої клінічної настанови, заснованої на доказах «Неалкогольна жирова хвороба печінки» (2012), згідно з рекомендаціями Європейської асоціації з вивчення печінки (EASL), наказу MO3 України №1118 від 21.12.2012 «Про затвердження та впровадження медико-технологічних документів зі стандартизації медичної допомоги при цукровому діабеті 2 типу», «Адаптованої клінічної настанови, заснованої на доказах «Цукровий діабет 2 типу», Свропейської асоціації з вивчення діабету (EASD), Свропейської асоціації з вивчення ожиріння (EASO) (2012). Установка і верифікація діагнозу НАЖХП проводилась на підставі стандартів обстеження хворих з гастроентерологічною патологією.

Діагноз НАЖХП був верифікований за допомогою проведеного дослідження функціонального стану печінки 3 використанням комплексу клініко-лабораторних, біохімічних та інструментальних методів. Вибірково 15 хворим діагноз НАЖХП був підтверджений за допомогою метода ультразвукової еластометрії - неінвазивного метода візуалізації фібротичних змін у печінці, який дозволяє оцінити рівень стеатозу печінки (Steato Test), ступінь активності запального процесу в печінці (Acti Test), piвень неалкогольного стеатогепатиту (Nash Test) і визначити ступінь фріброзу за шкалою Metavir (Fibro Test).

Ультразвукове дослідження (УЗД) органів черевної порожнини проводилося за допомогою апарату VOLUSON S10 (США).

Статистична обробка даних проводилася за допомогою розробленої карти для тематичних хворих, адаптованої до обробки отриманих показників за допомогою програми «Microsoft Excel», з використанням критерію Стьюдента, кореляційного аналізу за Пірсоном. Використані стандартні методи описової статистики, дисперсійного та регресійного аналізу. За рівень достовірності статистичних показників прийнято $\mathrm{p}<0,05$.

\section{РЕЗУЛЬТАТИ ТА ЇХ ОБГОВОРЕННЯ}

Серед клінічних проявів було відзначено переважання загальних симптомів, в тому числі: ксеростомія, поліурія, полідипсія, немотивована слабкість, зниження працездатності, психо-емоційна лабільність, головний біль, втрата маси тіла, періодичне відчуття важкості в правому підребер'ї, непереносимість жирної і смаженої їжі, молока, здуття живота.
Порівняно до контролю хворі на НАЖХП та ЦД 2 типу характеризувалися виразним підвищенням IMT( $<<0,001)$.

При дослідженні біохімічних показників були виявлені значні зміни в станах вуглеводного, білкового, пігментного і фpepментного обмінів (табл. 1). Таким чином, у обстежених хворих з НАЖХП і при ї̈ поєднанні з ЦД 2 типу з нормальною масою 
Показники вуглеводного, білкового, пігментного, ферментного обмінів ( $\mathrm{M} \pm \mathbf{m})$ у хворих на НАЖХП і при їі поєднанні з ЦД 2-го типу в залежності від IMT

\begin{tabular}{|c|c|c|c|c|}
\hline Показники & $\begin{array}{c}\text { Контрольна } \\
\text { група } \\
\mathbf{n}=20\end{array}$ & $\begin{array}{c}\text { НАЖХП } \\
\mathbf{n}=\mathbf{2 0}\end{array}$ & $\begin{array}{c}\text { НАЖХП + ЦД } \\
2 \text { типу } \\
\text { при нормальній } \\
\text { масі тіла } \mathbf{n}=\mathbf{2 0}\end{array}$ & $\begin{array}{c}\text { НАЖХП + ЦД } \\
2 \text { типу } \\
\text { при ожирінні } \\
\text { n = 35 }\end{array}$ \\
\hline $\begin{array}{c}\text { Глікемія натще, } \\
\text { ммоль/л }\end{array}$ & $3,85 \pm 0,16$ & $4,86 \pm 0,18$ & $9,10 \pm 0,23 * / * *$ & $9,74 \pm 0,11 * / * * / * * *$ \\
\hline $\mathrm{HbA}_{1 \mathrm{c}}(\%)$ & $4,72 \pm 0,05$ & $5,4 \pm 0,8^{*}$ & $7,3 \pm 0,15 * / * *$ & $11,03 \pm 0,28 * / * * / * * *$ \\
\hline $\begin{array}{l}\text { Інсулін } \\
\text { (пмоль/л) }\end{array}$ & $85,21 \pm 8,00$ & $88,5 \pm 6,5$ & $124,79 \pm 14,66$ & $143,45 \pm 19,35$ \\
\hline HOMA-IR y.o. & $1,49 \pm 0,25$ & $3,5 \pm 0,12^{*}$ & $12,89 \pm 0,62$ & $8,7 \pm 0,78 * / * * / * * *$ \\
\hline $\begin{array}{c}\text { Загальний білок } \\
\text { (г/л) }\end{array}$ & $68,7 \pm 0,2$ & $64,5 \pm 0,26^{*}$ & $63,21 \pm 0,12^{*}$ & $61,94 \pm 0,14 * / * * / * * *$ \\
\hline Альбуміни (\%) & $56,55 \pm 0,98$ & $53,2 \pm 0,32^{*}$ & $51,15 \pm 2,01 * / * *$ & $45,85 \pm 0,4 * / * * / * * *$ \\
\hline $\begin{array}{c}\text { Глобуліни (\%) } \\
\text { Альфа } 1\end{array}$ & $7,69 \pm 1,14$ & $8,49 \pm 0,14^{*}$ & $6,8 \pm 0,86 * / * *$ & $7,75 \pm 0,52 * / * * / * * *$ \\
\hline Альфра 2 & $8,8 \pm 1,98$ & $9,04 \pm 0,13^{*}$ & $9,64 \pm 1,66^{* / * *}$ & $11,61 \pm 1,78 * / * * / * * *$ \\
\hline Бета & $11,09 \pm 0,48$ & $9,98 \pm 0,23^{*}$ & $12,42 \pm 1,18 * / * *$ & $13,6 \pm 1,02^{*}$ \\
\hline Гама & $14,61 \pm 0,44$ & $18,2 \pm 0,25^{*}$ & $18,45 \pm 1,03 * / * *$ & $20,76 \pm 2,51 * / * * / * * *$ \\
\hline $\begin{array}{c}\text { Тимолова проба } \\
\text { (ОД) }\end{array}$ & $2,04 \pm 0,01$ & $3,12 \pm 0,26^{*}$ & $3,42 \pm 0,36 * / * *$ & $5,6 \pm 4,6^{*}$ \\
\hline $\begin{array}{c}\text { Білірубін загальний } \\
\text { (мкмоль/л) }\end{array}$ & $11,76 \pm 0,64$ & $22,94 \pm 0,74^{*}$ & $23,74 \pm 0,43 * / * *$ & $28,2 \pm 0,43 * / * * / * * *$ \\
\hline $\begin{array}{l}\text { Білірубін прямий } \\
\text { (мкмоль/л) }\end{array}$ & $4,5 \pm 1,13$ & $7,81 \pm 0,62^{*}$ & $12,64 \pm 0,83 * / * *$ & $16,54 \pm 0,86 * / * * / * * *$ \\
\hline ACT (Од/л) & $22,9 \pm 5,7$ & $38,1 \pm 1,1$ & $54,0 \pm 28,8 * / * *$ & $62,5 \pm 40,2 * / * * / * * *$ \\
\hline АЛТ(Од/л) & $24,8 \pm 5,1$ & $49,9 \pm 11,66^{*}$ & $54,7 \pm 12,73 * / * *$ & $58,0 \pm 6,72 * / * * / * * *$ \\
\hline ГГТ(Од/л) & $23,75 \pm 1,19$ & $28,2 \pm 11,2$ & $33,64 \pm 1,21 * / * *$ & $34,5 \pm 3,7 * / * * / * * *$ \\
\hline ЛФ (ОД) & $0,65 \pm 0,15$ & $2,18 \pm 0,14^{*}$ & $2,21 \pm 1,72 * / * *$ & $2,44 \pm 2,74 * / * * / * * *$ \\
\hline
\end{tabular}

Примітки:

* $\mathrm{p}<0,05-$ при порівнянні з показниками контрольної групи;

** $\quad$ p $<0,05-$ при порівнянні з показниками 1 -ої групи;

*** р $<0,05-$ при порівнянні з показниками 2-ї групи.

тіла або з ожирінням виявлені порушення пігментного, ферментного і білкового обміну, що відображають зміни функціонального стану печінки. Контроль за даними видами обміну мае важливе значення для оцінки стану печінки у хворих НАЖХП

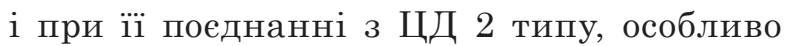
з наявності ожиріння.

Підвищення активності аспартатамінотрансферази (АСТ) і - аланінамінотрансферази (АЛТ), гаммаглутамінтрансферази (ГГТ) в сироватці крові, тенденція до підвищення білірубіну, переважно з підви- 
Показники мікро- і макроелементів сироватки крові $(\mathbf{M} \pm \mathbf{m})$ у хворих на НАЖХП і при її поеднанні з ЦД 2-го типу в залежності від IMT

\begin{tabular}{c|c|c|c|c}
\hline Показники & $\begin{array}{c}\text { Контрольна } \\
\text { група } \\
\mathbf{n = 2 0}\end{array}$ & $\begin{array}{c}\text { НАЖХП } \\
\mathbf{n = 2 0}\end{array}$ & $\begin{array}{c}\text { НАЖХП + ЦД } \\
\mathbf{2} \text { типу } \\
\text { при нормальній } \\
\text { масі тіла } \mathbf{n}=\mathbf{2 0}\end{array}$ & $\begin{array}{c}\text { НАЖХП + ЦД } \\
\mathbf{2} \text { типу } \\
\text { при ожирінні } \\
\mathbf{n}=\mathbf{3 5}\end{array}$ \\
\hline Цинк (мкмоль/л) & $27,53 \pm 0,3$ & $24,68 \pm 0,3^{*}$ & $23,67 \pm 0,3^{*}$ & $21,54 \pm 0,3^{*}$ \\
\hline Кальцій (ммоль/л) & $2,78 \pm 0,01$ & $1,72 \pm 0,32$ & $1,6 \pm 0,32$ & $1,28 \pm 0,06^{*}$ \\
\hline Магній (ммоль/л) & $2,84 \pm 0,08$ & $1,73 \pm 0,2^{*}$ & $1,63 \pm 0,2^{*}$ & $1,24 \pm 0,20^{*}$ \\
\hline Калій (ммоль/л) & $5,56 \pm 0,02$ & $4,35 \pm 0,06^{*}$ & $4,25 \pm 0,06^{*}$ & $3,44 \pm 0,46^{*}$ \\
\hline Натрій (ммоль/л) & $149,28 \pm 0,98$ & $139,4 \pm 1,8^{*}$ & $138,4 \pm 1,8^{*}$ & $132,16 \pm 0,2^{*}$ \\
\hline Мідь (мкмоль/л) & $13,76 \pm 1,99$ & $19,3 \pm 1,2^{*}$ & $18,3 \pm 1,2^{*}$ & $19,78 \pm 0,4^{*}$ \\
\hline Залізо (мкмоль/л) & $20,86 \pm 0,17$ & $18,28 \pm 0,4^{*}$ & $18,18 \pm 0,4^{*}$ & $17,16 \pm 0,4^{*}$ \\
\hline
\end{tabular}

Примітка:

* достовірно при порівнянні ідентичних показників кожної групи хворих з контролем $(\mathrm{p}<0,05)$.

і підвищенням глобулінів, як у паціентів з НАЖХП, НАЖХП та ЦД 2 типу, так і у паціентів з НАЖХП, ЦД 2 типу та ожирінням. Отримані дані дозволяють припустити наявність таких патологічних станів, як мезенхимально-запальний синдром (МЗС), печінково-клітинна недостатність [7]. На користь МЗС так само свідчить підвищення в обох групах показників тимолової проби. Відзначимо, що порушення пігментного обміну були сильніше виражені у хворих з НАЖХП і ЦД 2 типу при ожирінні. Показники загального білірубіну були достовірно вище в порівнянні з контрольною групою переважно за рахунок кон'югованої (прямої) фракції, в той час, як показник непрямого білірубіну залишався в межах норми. Отримані дані свідчать про наявність холестатичного синдрому різного ступеня тяжкості, в залежності від активності патологічного процесу в печінці. Дослідження ферментного обміну у хворих з коморбідних НАЖХП характеризувалися достовірним підвищенням активності ферментів, у тому числі органоспецифічних, індикаторних, а також екскреторних. Більш того спостерігалася пряма залежність даних показників від характеру клінічних проявів синдрому цитолізу і холестазу [7].

Таким чином, наявність НАЖХП у хворих з ЦД 2 типу при ожирінні сприяе по- рушенню вуглеводного, білкового, пігментного і ферментного обмінів так, як останні залежать від наявності патологічного процесу в печінці та ступеня його активності.

Дослідження мікро- і макроелементного складу сироватки крові у всіх групах хворих показало достовірне зниження вмісту цинку, магнію, кальцію, заліза, калію i натрію, а також збільшення показника міді (табл. 2).

Порівняльний аналіз серед хворих на НАЖХП та ЦД 2 типу і НАЖХП та ЦД 2 типу при ожирінні дозволив виявити негативний кореляційний зв'язок між рівнем каліємії, магніємії з ГКН $((\mathrm{r}=-0,27$; $\mathrm{p}<0,05)$ i $(\mathrm{r}=-0,37 ; \mathrm{p}<0,05)$, відповідно) i HbAc1 $((\mathrm{r}=-0,32 ; \mathrm{p}<0,05)$ i $(\mathrm{r}=-0,27$; $\mathrm{p}<0,05)$, відповідно). Позитивний кореляційний зв'язок спостерігався між показником міді і показниками вуглеводного обміну: ГКН в сироватці крові (відповідно: $\mathrm{r}=0,47 ; \mathrm{p}<0,05$ ) і HbAc1 (відповідно: $\mathrm{r}=0,38$; $\mathrm{p}<0,05)$.

В основі перерахованих вище змін ймовірно лежить зниження взаємодії глікогену з каліем і підвищення поглинання глюкози печінкою. Внаслідок втрати гепатоцитами здатності до поглинання калію, порушуеться процес утворення глікогену [5]. Брак магнію у хворих з коморбідністю НАЖХП та ЦД 2 типу при ожирінні негативно впливає на функції печінки, сприяючи роз- 
витку синдрому мінеральної недостатності, порушення утворення зв'язків з калієм, натрієм і кальцієм, а також до зміни метаболізму вуглеводів. Порушення метаболізму міді в групах хворих сприяе структурно-фрункціональним змінам у печінці, що виникають в результаті пригнічення процесів окислення глюкози і пригніченням метаболізму глікогену в тканинах печінки. Порушення метаболізму цинку у хворих, які беруть участь у проведеному дослідженні, сприяють погіршенню синтезу інсуліну, отже відбувається порушення метаболізму вуглеводів і реалізації біологічного ефекту інсуліну. Дані процеси призводять до зниження засвоєння глікогену гепатоцитами, що в свою чергу так само є причиною порушення фрункіонального стану печінки [8].
Варто відзначити, що при поєднанні НАЖХП з ЦД 2 типу при ожирінні крім порушення коригуючої функції печінки, так само спостерігаються підвищена проникність мембран клітин печінки, порушення форми і розмірів гепатоцитів i їx ядер, гіперхроматоз ядер гепатоцитів [9]. Причиною цього є порушення водно-сольового обміну: достовірне зниження в сироватці крові вмісту магнію, кальцію, цинку, заліза та підвищення показника міді. Такі зміни мікро- і макроелеметного складу крові безпосередньо пов'язані з виразністю патологічних процесів в тканинах печінки: дифузійною і запальною жировою інфільтрацією, білковою дистрофрією гепатоцитів, через нерівномірний розподіл глікогену в цитоплазмі гепатоцитів.

\section{ВИСНОВКИ}

1. Перебіг НАЖХП в поєднанні з ЦД 2-го типу супроводжуеться зміною показників біоелементного, вуглеводного і білкового обмінів.

2. Хронічна гіперглікемія і інсулінорезистентність здійснюють вплив на функціоальний стан печінки 3 порушенням метаболізму вуглеводів, яке зростає при поєднаному перебігу НАЖХП з ЦД 2-го типу, і ще більше посилюеться при наявності надлишкової маси тіла у даних хворих.

3. Дані проведеного комплексного клінічного та фрізикального обстеження, резуль- тати додаткових досліджень, дані УЗД дають можливість стверджувати, що НАЖБП є самостійним, незалежним, додатковим фрактором, який сприяе прогресуванню порушень обміну речовин в організмі.

4. Пріоритетним напрямком оптимізації діагностики хворих на НАЖХП, ЦД 2 типу і при їх поєднанні є глибинне вивчення впливу стану біоелементного обміну на фрормування і перебіг захворювання.

\section{ЛITEPAТУРА (REFERENCES)}

1. Afarideh M, Ghajar A, Noshad S, et al. Nutr Metab Cardiovasc Dis 2017; 27(1): 93-95. doi: 10.1016/j.numecd.2016.09.008.

2. Aigner E, Weiss G, Datz C. World J Hepatol 2015; 7(2): 177-188. doi: 10.4254/wjh.v7.i2.177.

3. Bril F, Cusi K. Diabetes Care 2017; 40(3): 419-430. doi:10.2337/dc16-1787.

4. Choi Y, Lee JE, Chang Y, et al. Br J Nutr 2016; 116(8): 1447-1456. doi: 10.1017/S0007114516003391.

5. Li W, Zhu X, Song Y, et al. Public Health Nutr 2018; 21(11): 2088-2095. doi: 10.1017/S1368980018000642.
6. Liang T, Zhang Q. Toxicol Lett 2015; 233: 114-124. doi: 10.1016/j.toxlet.2015.01.010.

7. Marreiro D, Cruz K, Morais J, et al. Antioxidants 2017; 6(2): 24. doi: 10.3390/antiox6020024.

8. Morrell A, Tallino S, Yu L, Burkhead JL. IUBMB Life 2017; 69(4): 263-270. doi: 10.1002/iub.1613.

9. Portillo-Sanchez P, Bril F, Maximos M, et al. J Clin Endocrinol Metab 2015; 100(6): 2231-2238. doi: 10.1210/ jc.2015-1966.

10. Ranasinghe P, Pigera S. Daru 2015; 23: 44. doi:10.1186/ s40199-015-0127-4. 


\title{
MIКРО- I МАКРОЕЛЕМЕНТНИЙ ОБМІН У ХВОРИХ НА НЕАЛКОГОЛЬНУ ЖИРОВУ ХВОРОБУ ПЕЧІНКИ І ПРИ ІЇ ПОЄДНАННІ З ЦУКРОВИМ ДІАБЕТОМ 2 ТИПУ
}

\author{
Журавльова Л. В., Лахно О. В., Цівенко О. І., Кривоносова О. М. \\ Харківський національний медичний університет, м. Харків, Украӥна \\ dr.lakhnoolga@gmail.com
}

Мета - вивчити зміни концентрації цинку, магнію, заліза, кальцію, калію, натрію, міді, а також з'ясувати зв'язок між концентраціями біоелементів з показниками функціонального стану печінки у хворих на неалкогольну жирову хворобу печінки (НАЖХП) і при її поєднанні з цукровим діабетом (ЦД) 2 типу в залежності від індексу маси тіла (IMT).

Обстежено 75 паціентів з НАЖХП і при ї̈ поєднанні з ЦД 2 типу - з нормальною масою тіла і ожирінням, у віці від 46 до 69 років, в тому числі 36 чоловіків і 39 жінок, з тривалістю захворювання від 3 до 15 років. Контрольну групу склали 20 практично здорових осіб. Програма дослідження включала визначення загальноклінічних показників, визначення дисбалансу біоелементів, вуглеводів, білків, оцінку структурного і функціонального стану печінки.

Результати. Дослідження мікро- і макроелементного складу сироватки крові у всіх групах хворих показало достовірне зниження вмісту цинку, магнію, кальцію, заліза, калію і натрію, а також збільшення показника міді, особливо в групі хворих з підвищеним IMT.

Висновки. В результаті дослідження, було виявлено порушення мікро- складу сироватки крові у всіх групах хворих. Визначено достовірне зниження вмісту цинку, магнію, кальцію, заліза, калію і натрію, а також збільшення показника міді. Виявлено зв'язок між концентраціями мікро- та макроелементів із показниками функціонального стану печінки у хворих на НАЖХП і при їі поєднанні з ЦД 2 типу в залежності від IMT. При поєднаному перебігу НАЖХП і ЦД 2 типу за наявності ожиріння зміни показників мікро- і макроелементного, вуглеводного і білкового обмінів та функціонального стану печінки були більш виражені.

К л ючові слова: цукровий діабет 2 типу, неалкогольна жирова хвороба печінки, мікроелементи, макроелементи.

\section{MICRO- AND MACRONUTRIENT METABOLISM IN PATIENTS WITH NON-ALCOHOLIC FATTY LIVER DISEASE AND IN COMBINATION WITH TYPE 2 DIABETES MELLITUS}

Zhuravlova L. V., Lakhno O. V., Tsyvenko O. I., Kryvonosova O. M.

\author{
Kharkiv National Medical University, Kharkiv, Ukraine \\ dr.lakhnoolga@gmail.com
}

The purpose is to study changes in the concentration of zinc, magnesium, iron, calcium, potassium, sodium, copper, as well as to find out the relationship between the concentrations of micro - and macronutrients with liver function indicators in patients with non-alcoholic fatty liver disease (NAFLD) and in combination with type 2 diabetes mellitus (DM), depending on body mass index (BMI).

75 patients with (NAFLD) and in combination with type $2 \mathrm{DM}$ - with normal body weight and obesity, aged 46 to 69 years, including 36 men and 39 women, with a duration of the disease from 3 to 15 years were examined. The control group consisted of 20 practically healthy people. The study program included determination of general clinical indicators, determination of the imbalance of bioelements, carbohydrates, proteins, assessment of the structural and functional state of the liver.

Results. The study of the bioelements composition of blood serum in all groups of patients showed a significant decrease in the content of zinc, magnesium, calcium, iron, potassium and sodium, as well as an increase in the copper especially in the group of patients with an increased BMI.

Conclusions. As a result of the study, a violation of the microcomposition of blood serum was revealed in all groups of patients. A significant decrease in the content of zinc, magnesium, calcium, iron, potassium and sodium, as well as an increase in the copper, was determined. A relationship was found between bioelements concentrations and liver function indicators in patients with NAFLD and in combination with type 2 DM, depending on BMI. With the combined course of NAFLD and type $2 \mathrm{DM}$ in the presence of obesity, changes in, carbohydrate and protein metabolism, and the functional state of the liver were more pronounced.

Key words: type 2 diabetes mellitus, non-alcoholic fatty liver disease, trace elements, macronutrients. 